\title{
THE EFFECT OF LEVEL OF NON-DEGRADABLE PROTEIN IN DIET ON FATTENING PARAMETERS AND DIGESTIBILITY OF NUTRIENTS IN LAMBS
}

\author{
D. Ružić-Muslić ${ }^{\text {, M.P. Petrović }}{ }^{1}$, Z. Bijelić ${ }^{1}$, M. Žujović ${ }^{1}$, P. Perišić ${ }^{2}$, N. \\ Maksimović $^{1}$ \\ ${ }^{1}$ Institute for Animal Husbandry, Belgrade-Zemun, 11080, Serbia \\ ${ }^{2}$ Faculty of Agriculture, Belgrade-Zemun, 11080, Serbia \\ Corresponding author: muslic.ruzic@.gmail.com \\ Original scientific paper
}

Abstract: Results of the study of the effect of the level of nondegradable protein in diet on fattening performance and digestibility of nutrients in weaned lambs are presented in the paper. Objective of the study was to establish the optimal level of non-degradable protein in diets for weaned and intensively fattened lambs. Experiment was conducted on 60 lambs of $F_{1}$ generation: Pirot Pramenka $\mathrm{x}$ Wurttemberg $\mathrm{x}$ Ile de France, weaned at the age of 60 days and divided into three groups. The effect of use of three concentrated mixtures which differed in the share of protein non-degradable at the level of rumen: $43 \%$ (I), 51\% (II) and 58\% (III). Average daily gain of lambs fed types of mixtures I:II:III was 0.169: 0.205: $0.227 \mathrm{~kg}$, respectively. Dry matter conversion $(\mathrm{kg} / \mathrm{kg}$ of gain) on analogue treatments was: $4.54: 3.71: 3.30$, respectively, of energy (MJ NEM/kg) : 33.77: $29.37: 26.25$, and of total proteins $(\mathrm{g} / \mathrm{kg}): 732: 596: 549$. Level of intake of proteins was not influenced by the treatment considering that the digestibility coefficients recorded were: $52.58 \%: 51.30 \%: 55.12 \%$. With the increase of the share of non-degradable protein in concentrate mixtures, the tendency of increase of the digestibility of fat was present: $76.13: 77.98$ $: 87.17 \%$, as well as of decrease of the intake of fibre: $67.40: 45.87: 22.39 \%$ and NFE: $83.87: 76.05: 82.96 \%$. Values of the dressing percentage of warm carcass with giblets according to nutrition types I:II:III were: 58.70 : 58.02 : $57.42 \%$, respectively. percentage.

Key words: lambs, non-degradable protein, yield, digestibility, dressing 


\section{Introduction}

Proteins contained in food which reach small intestines of ruminants represent sum of two protein fractions: microbial and protein non-degradable at the level of rumen. Micro-organisms in reticulum-rumen degrade the protein contained in the diet to peptides, amino acids and ammonia, and subsequently these substances are used for synthesis of own proteins. In each of these processes of degradation and synthesis there are certain losses which means that reduced amount of amino acids arrives to the place of digestion and protein intake (Grubic et al., 1992). In order to provide optimal amount of amino acids for specific production, it is necessary to ensure in the diet for lambs protein fraction which avoids degradation in reticulum-rumen (non-degradable protein). This is especially important in intensive lamb fattening, considering that with the increase of genetic capacities of lambs their requirements increase, especially in the protein fraction which passes non-degraded through rumen and together with the microbial protein arrives to duodenum (Ružić-Muslić, 2006).

Taking this into consideration, aim of this study was to investigate the effect of different levels of non-degradable proteins in diets on fattening performance and level of intake of nutrients in intensively fattened lambs.

\section{Materials and Methods}

Trial included 60 lambs of $F_{1}$ generation: Pirot Pramenka x Wurttemberg $x$ Ile de France, weaned at the age of 60 days and divided into three homogeneous groups. Average body mass of lambs at the beginning of trial was approx. $18,0 \mathrm{~kg}$. Nutrition of lambs consisted of fodder mixtures and hay, lambs were fed in group and ad libitum. Three mixtures were studied which differed in the share of nondegradable protein in reticulum-rumen ( $43: 51: 58 \%)$, which was accomplished by using of different protein sources: sunflower meal (nutrition type I), soy bean meal (nutrition type II) and fish meal (nutrition type III). Body mass of lambs in trial was determined by weighing of animals in 15 day intervals. Feed conversion was calculated based on realized gain and consumption of food between weighing. Nutritional value was calculated based on French system recommended by INRA $\left(1988^{* *}\right)$ and Obračević $\left(1990^{*}\right)$. Structure of concentrate mixtures is presented in Table 1, and their nutritional value in Table 2. 
Table 1. Structure of concentrate mixtures used in fattening of weaned lambs, \%

\begin{tabular}{|l|c|c|c|}
\hline \multirow{2}{*}{ Feeds } & \multicolumn{3}{|c|}{ Concentrate mixtures } \\
\cline { 2 - 4 } & I & II & III \\
\hline Corn & 73 & 79 & 82 \\
\hline Sunflower meal & 23 & 5 & 7 \\
\hline Soy bean meal & 0 & 12 & 0 \\
\hline Fish meal & 0 & 0 & 2 \\
\hline Limestone & 2 & 2 & 1 \\
\hline Salt & 1 & 1 & 1 \\
\hline Premix & 1 & 1 & \\
\hline
\end{tabular}

Table 2. Nutritional value of mixtures

\begin{tabular}{|l|c|c|c|}
\hline \multirow{2}{*}{ Nutritional indicators } & \multicolumn{3}{|c|}{ Concentrate mixtures } \\
\cline { 2 - 4 } & I & II & III \\
\hline Dry matter & 87.1 & 86.5 & 86.8 \\
Oats nutritional units & 1.2 & 1.2 & 1.2 \\
NEM;MJ/kg(*) & 7.51 & 7.98 & 7.91 \\
Total protein & 142 & 137 & 141 \\
NP in CP(**) & $\mathbf{4 3}$ & $\mathbf{5 1}$ & $\mathbf{5 8}$ \\
PDIN,g/animal/day & 102 & 103 & 107 \\
PDIE,g/animal/day & 102 & 112 & 118 \\
Ashes & 25 & 23 & 27 \\
Ca,g & 8.4 & 8.2 & 10.6 \\
P,g & 4.6 & 3.7 & 5.0 \\
\hline
\end{tabular}

Investigation of the digestibility of nutrients was done using indirect method on 18 male animals, divided in three groups, of average body mass of approx. $35.0 \mathrm{~kg}$. These investigations included preparation period (7 days) and collection period (6 days). During whole period lambs received twice a day measured amount of concentrate with different share of non-degradable protein, to which $\mathrm{Cr}_{2} \mathrm{O}_{3}$ was added as indicator, in concentration of $0.5 \%$.

During collection period, after every feeding, faeces samples were collected (in the amount of $150 \mathrm{~g}$ ), from each animal and placed in special dish, with designation of the animals, group, time and date of faeces collection. After the end of trial period, samples from each dish were well homogenized and a representative 
sample for analysis was made. Samples and food and faeces remains were analyzed using the standard method of chemical analysis (WENDE). Data obtained by analytical method were used for calculation of the digestibility of nutrients indirectly, according to following formula:

Digestibility, $\%=100-\frac{(\% \text { indic. in food }}{\% \text { indic. in faeces }} \times \frac{\% \text { nutrients in faeces }) \times 100}{\% \text { nutrients in food }}$

At the end of the trial, for the purpose of determination of meat yield, randomly 18 animals were chosen (6 for each treatment), slaughtered and processed in a usual way in the Experimental slaughterhouse of the Institute for Animal Husbandry. After cooling in duration of 24 hours at the temperature of 0 to $+4{ }^{0} \mathrm{C}$ mass of cold carcasses was determined together with the head and giblets, as well as the mass of cold carcasses without offal.

Statistical processing of data was done using program Stat. Soft, Inc. (2003) STATISTICA (data analysis software system), version 6, using standard mathematical-statistical methods.

\section{Results and Discussion}

Data on average fattening performance realized in different treatments are presented in Table 3.

Table 3. Fattening performance of trial lambs

\begin{tabular}{|l|c|c|c|}
\hline \multicolumn{1}{|c|}{ Indicators } & \multicolumn{3}{|c|}{ Nutrition type } \\
\cline { 2 - 4 } & I & II & III \\
\hline $\begin{array}{l}\text { Body mass of animal } \\
\text { at the beginning of trial, kg }\end{array}$ & 18.08 & 18.12 & 18.17 \\
$\begin{array}{l}\text { Age of animals } \\
\text { at the beginning of trial, days }\end{array}$ & 60 & 60 & 60 \\
$\begin{array}{l}\text { Body mass of animal } \\
\text { at the end of trial, } \mathrm{kg}\end{array}$ & & & \\
$\begin{array}{l}\text { Total gain, kg } \\
\text { Average daily gain, } \mathrm{kg}\end{array}$ & 12.70 & $33.52^{* *}$ & $35.17^{* *}$ \\
\hline
\end{tabular}

$* * *(\mathrm{P}<0.001) \quad * * \quad(\mathrm{P}<0.01)$

Level of non-degradable protein in diet had very significant $(\mathrm{P}<0.01)$ effect on final fattening performance expressed by daily gain: 0.169 (I), 0.205 (II) and 
0.227 (III) $\mathrm{kg}$, i.e. final body mass of trial animals: $30.78 \mathrm{~kg}$ (I); $33.52 \mathrm{~kg}$ (II) and $35.17 \mathrm{~kg}$ (III). It is known that in ruminants micro-organisms in rumen degrade diet protein to peptides, amino acids and ammonia, and subsequently these substances are used for synthesis of own proteins. In each of these processes of degradation and synthesis there are certain losses (usually around $20 \%$, sometimes even more), which means that reduced amount of amino acids arrives to the place of digestion and protein intake. If the volume of degradation is greater, proportionally lower amount of amino acids remains directly for the animal (Grubić et al.1992).Specific role of amino acids absorbed from small intestines is synthesis of proteins which contributes to growth of body tissues. This is especially important in intensive fattening of weaned lambs which are characterized with high genetic capacity for growth. So, feeds whose proteins remained to large extent nondegraded in the reticulum-rumen and arrived to duodenum (fish meal, soy bean meal) enabled realization of higher yields of lambs. Confirmation of these results we find in studies of Orskova et al. (1971), Miller (1978), Grubić et al. (1991), Walza et al. (1998), Peter et al. (2000), Memiši et al. (2002).

Table 4. Consumption of food and nutrients per kilogram of gain of lambs $(\mathrm{kg} / \mathrm{kg})$

\begin{tabular}{|l|c|c|c|}
\hline \multirow{2}{*}{ Feeds } & \multicolumn{3}{|c|}{ Nutrition type } \\
\cline { 2 - 4 } & I & II & III \\
\hline Concentrate mixture & 3.65 & 3.10 & 2.83 \\
\hline Alfalfa hay & 1.50 & 1.09 & 0.91 \\
\hline DM & 4.54 & 3.71 & 3.30 \\
\hline CP,g/kg & 732 & 596 & 549 \\
\hline PDIN,g/kg & 502 & 414 & 381 \\
\hline PDIE,g/kg & 480 & 425 & 396 \\
\hline MEM,MJ/kg & 33.77 & 29.37 & 26.25 \\
\hline
\end{tabular}

Results pertaining to consumption of food and nutrients are presented in Table 4. The most favourable DM conversion was established in lambs fed diets with fish meal (III) which used $27.31 \%$ less DM per $\mathrm{kg}$ of gain compared to animals fed diets with sunflower meal (I) and $11.05 \%$ less compared to treatment with soy bean meal (II). Also, the least consumption of protein per unit of growth was established in lambs on nutrition type III which, in relation to animals on treatments I and II, consumed by $25 \%$ and $7.88 \%$ less protein, respectively. With the increase of share of non-degradable protein in total proteins, the use of energy decreased by $4.4-7.5$ MJ NEM for every kilogram of realized gain. Data on conversion of food and nutrients obtained in this research are in accordance with results obtained by Kozarovski (1988), Grubić et al. (1991), Mekić (1994), who 
also established that with the increase of the share of non-degradable in total proteins in diet, the consumption of food and nutrients per kilogram of realized gain decreased.

Results presented in Table 5 are average coefficients of nutrient digestibility depending on the nutrition treatment.

Table 5. Digestibility of nutrients, \%

\begin{tabular}{|c|c|c|c|}
\hline \multirow[t]{2}{*}{ Nutrients } & \multicolumn{3}{|c|}{ Nutrition types } \\
\hline & I & II & III \\
\hline Total protein & 52.58 & 51.30 & 55.12 \\
\hline Crude fat & 76.13 & $77.98^{*}$ & $87.17^{*}$ \\
\hline Crude fibre & 67.40 & $45.87^{* *}$ & $22.39^{* * *}$ \\
\hline NFE & 83.87 & $76.05^{*}$ & 82.96 \\
\hline
\end{tabular}

Average coefficients of total protein digestibility in lambs fed concentrate mixtures containing $43: 51: 58 \%$ NP were: $52.58 \%: 51.30 \%: 55.12 \%$ respectively. In calculation of digestibility of these substances endogenous protein fraction had not been eliminated, so values obtained in this way represent apparent digestibility of total proteins which partially explains slightly lower values of the protein digestibility coefficients. Established differences in protein digestibility between lambs on treatments I:II:III ranged within limits of random deviations $(\mathrm{P}>0.05)$.

By analysis of obtained coefficients of digestibility a significant effect of the level of non-degradable protein on the level of fat absorption is registered. The lowest digestibility of $76.13 \%$ was realized in lambs on treatment I, and the highest $(87.17 \%)$ on treatment III. whereas digestibility of fat in lams of treatment II was $77.98 \%$. Established difference of 11.04 percentage units between treatments I and III was statistically significant $(\mathrm{P}=0.01)$. Also, difference in digestibility of fat between animals on treatments II and III of 9.19 percentage units was statistically confirmed $(\mathrm{P}=0.02)$. So, with the increase of share of non-degradable proteins (43:51:58\%) a tendency of increase of fat digestibility was registered.

Average coefficients of digestibility of crude fibre in lambs on treatments I:II:III were: $67.40 \%: 45.87 \%: 22.39 \%$. Established difference in level of intake of crude fibre of 21.53 percentage units between lambs on treatments I and II was statistically highly significant $(\mathrm{P}=0.006)$ as well as difference of 23.48 percentage units between lambs on nutrition types II and III $(\mathrm{P}=0.004)$. At the same time, 
established difference in digestibility of 45.01 units between animals on treatments I and III was statistically highly significant $(\mathrm{P}=0.0003)$.

Level of intake of NFE in lambs on nutrition treatments I:II:III was: $83.87 \%$ (I), $76.05 \%$ (II) and $82.96 \%$ (III), which indicated presence of certain tendency of decrease of digestibility with the increase of share of NP in total proteins. Difference in NFE digestibility between lambs of II and I group was statistically confirmed $(\mathrm{P}=0.01)$.

Average values of carcass mass and dressing percentage are presented in Table 6.

Table 6. Average values of carcass mass and dressing percentage

\begin{tabular}{|c|c|c|c|c|c|c|}
\hline \multirow{3}{*}{ Indicators } & \multicolumn{6}{|c|}{ Nutrition type } \\
\hline & \multicolumn{2}{|c|}{ I } & \multicolumn{2}{|c|}{ II } & \multicolumn{2}{|c|}{ III } \\
\hline & $x$ & $\mathrm{Sd}$ & $\mathrm{x}$ & $\mathrm{Sd}$ & $\mathrm{x}$ & $\mathrm{Sd}$ \\
\hline $\begin{array}{l}\text { Pre-slaughter lamb } \\
\text { mass, kg }\end{array}$ & 30.78 & 4.73 & 33.52 & 4.99 & 35.17 & 5.34 \\
\hline $\begin{array}{l}\text { Mass of warm carcass } \\
\text { with offal, } \mathrm{kg}\end{array}$ & 18.07 & 2.86 & 19.45 & 3.02 & 20.19 & 3.31 \\
\hline $\begin{array}{l}\text { Dressing percentage, } \\
\text { warm carcass with } \\
\text { offal, } \%\end{array}$ & 58.70 & 1.14 & 58.02 & 1.65 & 57.42 & 1.47 \\
\hline $\begin{array}{l}\text { Dressing percentage, } \\
\text { cold carcass with } \\
\text { offal, } \%\end{array}$ & 56.49 & 1.37 & 55.97 & 1.78 & 55.38 & 1.22 \\
\hline $\begin{array}{l}\text { Mass of cold carcass } \\
\text { without offal, } \mathrm{kg}\end{array}$ & 15.44 & 2.22 & 17.21 & 2.40 & 17.36 & 2.57 \\
\hline $\begin{array}{l}\text { Dressing percentage, } \\
\text { cold carcass without } \\
\text { offal.\% }\end{array}$ & 46.45 & 1.25 & 46.14 & 1.72 & 45.42 & 1.27 \\
\hline
\end{tabular}

As presented in Table 6, values of the dressing percentage of warm carcass with offal, according to nutrition treatments I:II:III were: $58.70: 58.02: 57.42 \%$, respectively, and values of dressing percentage of cold carcass without head and offal: $46.45: 46.14: 45.42 \%$ respectively. Established differences ranged within limits of random deviations ( $\mathrm{P}>0.05)$, which means that different levels of nondegradable protein in diets for lambs had no significant effect on investigated traits. Obtained results are in accordance with results of Šokarovski (1988) and Mekić (1997). 


\title{
Conclusion
}

Based on obtained results of the investigation of the effect of different levels of non-degradable protein in diets on fattening performance and nutrient digestibility in lambs, the following can be concluded:

The highest average daily gain $(0.227 \mathrm{~kg})$ was realized by lambs fed diet containing $58 \% \mathrm{NP}$.

The best conversion of DM $(3.30 \mathrm{~kg} / \mathrm{kg}$ gain) was realized by lambs on treatment III.

Different levels of non-degradable protein (43:51:58\%) had no significant effect on level of intake of total protein.

With the increase of share of non-degradable protein a tendency of increase of fat digestibility was registered.

Levels of intake of fibre and NFE had decreasing trend with the increase of the level of non-degradable protein.

Value of the dressing percentage of warm carcass with offal, on nutrition types I:II:III, were: $58.70: 58.02: 57.42 \%$ respectively.

These researches were conducted before the ban of animal feeds, i.e. fish meal in ruminant nutrition. Obtained results showed that the best performance in regard to body mass, growth intensity, food utilization and level of nutrient intake was realized by lambs on treatment III which received in the concentrate mixture $58 \%$ of NP, whereas the dressing percentage was not under significant influence of the treatment.

\section{Uticaj nivoa nerazgradivog proteina u oborku na tovne parametre i svarljivost hranljivih materija kod jagnjadi}

\author{
D. Ružić-Muslić, M.P. Petrović, Z. Bijelić, M. Žujović, P. Perišić, N. Maksimović
}

\section{Rezime}

U radu su prikazani rezultati ispitivanja uticaja različitih nivoa nerazgradivog proteina $u$ obroku (43:51:58\%) na tovne performanse i svarljivost hranljivih materija kod intenzivno tovljene jagnjadi.

Ogled je izveden na 3 grupe po 20 meleza $F_{1}$ generacije : pirotska pramenka x virtemberg x Ile de France zalučenih u uzrastu od 60 dana. Jagnjad su hranjena lucerkinim senom i izoproteinskim krmnim smešama koje su se razlikovale u pogledu udela nerazgradivog proteina. Dobijeni podaci su obrađeni standardnom statističkom analizom.

Prosečna telesna masa jagnjadi na početku ogleda, na tretmanima I: II: III je iznosila: 18,08:18,12:18,17 kg, a na kraju : 30,78, 33,52 i $35,17 \mathrm{~kg}$, dok je prosečan dnevni prirast bio: $0,169: 0,205: 0,227 \mathrm{~kg}$. Po kilogramu prirasta 
jagnjadi je utrošeno: 4,54:3,71:3,30 kg suve materije; energije: 33,77: 29,37 : 26,25 MJ; ukupnih proteina: $732: 596: 549 \mathrm{~g}$;

Stepen usvajanja proteina nije bio pod uticajem ispitivanog tretmana, $\mathrm{s}$ obzirom da su koeficijenti svarljivosti iznosili: 52,58\% : 51,30\% : 55,12\%. Sa povećanjem udela nerazgradivog proteina u smešama koncentrata, prisutna je tendencija povećanja svarljivosti masti : 76,13:77,98:87,17\%, a smanjenja stepena usvajanja celuloze: $67,40: 45,87: 22,39 \%$ i BEM-a: $83,87: 76,05: 82,96 \%$.

Vrednosti randmana toplog trupa sa glavom i iznutricama su iznosile: 58,70: 58,02 : $57,42 \%$. Ova istraživanja su pokazala da su najbolje tovne performanse postigla jagnjad na tretmanu sa $58 \% \mathrm{NP}$, dok randman nije bio pod značajnijim uticajem ispitivanog tretmana.

\section{References}

GRUBIĆ G., ZEREMSKI D., PAVLIČEVIĆ A. (1991): Uticaj razgradivosti proteina hrane na proizvodne rezultate odlučene jagnjadi. Zbornik radova Poljoprivrednog fakulteta, godina 36, sveska 595, 169-183, Beograd

GRUBIĆ G., ADAMOVIĆ M., NEGOVANOVIĆ D. (1992): Razgradivost proteina kao kriterijum za sastavljanje obroka u ishrani preživara. Inovacije u stočarstvu, X, 125-131.

KOZAROVSKI N. (1988): Uticaj razgradivosti na hranljivu vrednost proteina u ishrani tovne jagnjadi. Doktorska disertacija. Poljoprivredni fakultet, Novi Sad.

MEKIĆ C. (1994): Ispitivanje reproduktivnih i proizvodnih osobina ovaca Ile de France rase. Doktorska disertacija, Poljoprivredni fakultet, Beograd.

MEKIĆ C., GRUBIĆ G., PETROVIĆ P.M., STOJKOVIĆ M., RADOVIĆ M (1999): Uticaj izvora proteina u obroku na prinos i kvalitet mesa jagnjadi Ile de France rase. Savremena poljoprivreda, 48, 1-2, 237-244.

MEMIŠI N., BAUMAN F., GRUBIĆ G., KOLJAJIĆ V., PAVLOV B. (2002): Uticaj različitih izvora nerazgradivog proteina $\mathrm{u}$ obroku na proizvodna svojstva rano odlučene jagnjadi u tovu. Biotehnologija u stočarstvu 18, 5-6, 213-219.

MILLER E.L. (1978): Evaluating the protein contribution of feedsuffs for ruminants. Tech. Bull. No 5, IA FMM

ORSKOV E.R., MCDONALD I., FRASER C., CORSE E.L. (1971): The nutrition of the early weaned lamb. III The effect of ad libitum intake of diets varying in protein concentration on performance and on bory composition at differenty live weights. Journal of Agricultural Science, 77, 351-361.

PETER S., ERICKSON B., BARTON A. (2000): Whole soybeans for market lambs. Journal Animal Science, 1249-1270.

PETROVIĆ P.M. (2000): Genetika i oplemenjivanje ovaca, Naučna, Beograd,365 pp.

RUŽIĆ-MUSLIĆ D. (2006): Uticaj različitih izvora proteina u obroku na proizvodne rezultate jagnjadi u tovu. Doktorska disertacija, Poljoprivredni fakultet, Beograd-Zemun. 
SHAHRBABAK SOFLAEI M., ROZBAHAN Y., SHAHRBABAK MORADI M., SHAHRBABAK MORADI H. (2009): Influence of different levels of digestible undegradable protein on the carcass characteristic of Kermani male lambs in Iran.International Journal of Agriculture and Biology, 11, 643-646

ŠOKAROVSKI J., TOKOVSKI N., JORDANOSKI N. (1988): Uticaj genetskih i nutritivnih faktora na proizvodna svojstva i kvalitet trupa rano odbijene $\mathrm{i}$ intenzivno tovljene jagnjadi. Krmiva, 30, 7-8, 129-137.

WALZ L.S., WHITE T.W., FERNANDEZ J.M., GENTRY L.R., BLOURN D.C. FROATSCHEL M.A., BROWN T.F., LUPTON C.J., CHAPA A.M. (1998): Effects of fish meal and sodium bentonite on daily gain, wool, growth, carcass characteristics and ruminal and blood characteristics of lambs fed concentrate diets. J. Anim. Sci., 76, 2025-2031

Received 6 September 2010; accepted for publication 15 September 2010 